\title{
Editorial 66
}

\section{Eric Scerri ${ }^{1}$}

Published online: 7 August 2020

(c) Springer Nature B.V. 2020

One of the most gratifying aspects of the development of ISPC has been the way in which it has grown internationally. For example, over the past few years there has been a strong Italian contingent represented at our annual meetings. In fact, the most recent such meeting was held about a year ago at the University of Turin and superbly organized by Elena Ghibaudi and Lugi Cerruti from the chemistry department at that institution. The issue before you is comprised of papers that were presented at this meeting.

I first came into contact with Elena Ghibaudi 7 years ago following the publication of an article that she authored with two colleagues on the dual nature of the concept of an element. ${ }^{1}$ In addition to Elena's entry into the ISPC, I am pleased to say that our collaboration together has just resulted in a co-edited book of articles on this theme that includes contributions from many of the leading philosophers of chemistry who are currently active. ${ }^{2}$

Nevertheless, the focus here is the special issue for the Turin meeting for which Ghibaudi and her colleague, the distinguished chemical historian, Luigi Cerruti, have written an introduction that appears in the following pages of this issue. I leave it to them to set the scene.

Publisher's Note Springer Nature remains neutral with regard to jurisdictional claims in published maps and institutional affiliations.

${ }^{1}$ E.M. Ghibaudi, A. Regis, E. Roletto, What do chemists mean when they talk about elements? Journal of Chemical Education, 90(12),1626-1631, 2013.

${ }^{2}$ Eric R. Scerri, E.M. Ghibaudi, What is an element? Oxford University Press, New York, 2020.

Eric Scerri

scerri@chem.ucla.edu

1 Department of Chemistry and Biochemistry, UCLA, Los Angeles, CA 90095, USA 